\title{
Persepsi Mahasiswa Fakultas Ekonomi Universitas Islam Riau Tentang Ekonomi Syariah
}

\author{
Zulfadli Hamzah ${ }^{1}$ \& Rifqi Azien Dani2* \\ * Fakultas Agama Islam (FAI) Universitas Islam Riau (UIR) Pekanbaru \\ Jl. Kaharuddin Nasution No. 113 Perhentian marpoyan Pekanbaru 28284 \\ e-mail : zulfadlihamzah@fis.uir.ac.id, rifqiazien61@gmail.com.
}

\begin{abstract}
Abstrak : Saat sekarang ini sudah banyak perguruan tinggi Negeri maupun Swasta yang membuka program studi ekonomi Islam. Selain itu terdapat beberapa Fakultas Ekonomi konvensional yang telah menambahkan mata kuliah tentang ekonomi syariah di dalam kurikulumnya, salah satunya adalah Fakultas Ekonomi Universitas Islam Riau. Penelitian ini dilakukan untuk mengetahui persepsi mahasiswa Fakultas Ekonomi Universitas Islam Riau tentang ekonomi syariah. Penelitian ini bersifat deskriftif. Populasi dalam penelitian ini sebanyak 3182 orang dengan sampel sebanyak 187 orang mahasiswa. Penelitian ini merupakan statistik deskriptif yaitu penyajian data dengan mengunakan tabel, diagram lingkar dan persentase. Data yang digunakan dalam penelitian ini adalah data primer dan data sekunder. Pengumpulan data primer dilakukan dengan cara menyebar angket sedangkan pengumpulan data sekunder dari bahan bacaan seperti buku. Dari 187 responden yang menyatakan sangat setuju sebanyak 3455 atau $24 \%$, responden yang menyatakan setuju sebanyak 7320 atau $51 \%$, responden yang menyatakan netral sebanyak 3318 atau $23 \%$, responden yang menyatakan tidak setuju sebanyak 194 atau $2 \%$ dan responden yang menyatakan sangat tidak setuju sebanyak 16 orang atau $0 \%$. Berdasarkan analisis data hasil penelitian ini menunjukkan rata-rata skor penilitian sebesar 715 terletak pada daerah "Setuju", dengan persentase $72 \%$, yang berarti persepsi mahasiswa Fakultas Ekonomi Universitas Islam Riau tentang ekonomi syariah adalah "Baik".
\end{abstract}

Kata Kunci : Persepsi, Mahasiswa, Ekonomi Syariah 


\section{PENDAHULUAN}

Saat sekarang ini sudah banyak perguruan tinggi Negeri maupun Swasta yang membuka program studi ekonomi Islam. Di Pekanbaru sendiri terdapat beberapa perguruan tinggi yang membuka program studi ekonomi syariah Diantaranya adalah Universitas Islam Riau, Universitas Islam Negeri Sultan Syarif Kasim, STIES Imam Syafii, STAI Diniyah dan STEI Iqra Annisa.

Selain itu terdapat beberapa Fakultas Ekonomi konvensional yang sekarang ini sudah mulai menambahkan mata kuliah tentang ekonomi syariah di dalam kurikulumnya, salah satunya adalah Fakultas Ekonomi Universitas Islam Riau. Fakultas ini memiliki empat program studi yaitu ekonomi pembangunan, manajemen, akuntansi S1 dan akuntansi D3 dimana program studi ekonomi pembagunan terdapat mata kuliah ekonomi Islam di semester 3 dan perbankan syariah di semester 5 , pada program studi manajemen itu sendiri terdapat mata kuliah ekonomi Islam di semester 3, manajemen perbankan syariah dan asuransi syariah di semester 5 . Pada program studi akuntansi S1 juga terdapat mata kuliah ekonomi Islam di semester 3 dan akuntansi perbankan syariah di semester 4 , sedangkan akuntansi D3 terdapat mata kuliah ekonomi Islam di semester 4 dan akuntansi perbankan syariah di semester 6 . Tidak hanya di dalam kelas mereka juga aktif dalam organisasi ForSEI (Forum Studi Ekonomi Islam) dengan membuat kajian-kajian dan seminar yang bertemakan ekonomi syariah.

Berikut merupakan data mahasiswa Fakultas Ekonomi Universitas Islam Riau dari angkatan 2015-2018:

Tabel 1 : Data Mahasiswa Fakultas Ekonomi Universitas Islam Riau

\begin{tabular}{|c|c|c|c|c|c|c|}
\hline \multirow[b]{2}{*}{ No } & \multirow[b]{2}{*}{ Tahun } & \multicolumn{4}{|c|}{ Jurusan } & \multirow[b]{2}{*}{ Jumlah } \\
\hline & & $\begin{array}{l}\text { Ekonomi } \\
\text { Pembangunan }\end{array}$ & Manajemen & $\begin{array}{l}\text { Akuntansi } \\
\text { S1 }\end{array}$ & $\begin{array}{l}\text { Akuntansi } \\
\text { D3 }\end{array}$ & \\
\hline 1. & 2015 & 52 & 583 & 412 & - & 1047 \\
\hline 2. & 2016 & 84 & 575 & 362 & 26 & 1047 \\
\hline 3. & 2017 & 68 & 566 & 431 & 23 & 1088 \\
\hline 4. & 2018 & 29 & 592 & 408 & 11 & 1040 \\
\hline \multicolumn{6}{|c|}{ Total } & 4222 \\
\hline
\end{tabular}

Sumber : TU Fakultas Ekonomi, 2018.

Dari tabel di atas bahwasanya jumlah mahasiswa Fakultas Ekonomi Universitas Islam Riau pada tahun 2015 berjumlah 1047 mahasiswa dimana untuk program studi ekonomi pembangunan berjumlah 52 mahasiswa, program studi manajemen berjumlah 583 mahasiswa, program studi akuntansi S1 berjumlah 412 mahasiswa

dan program studi akuntansi D3 tidak ada mahasiswa yang mendaftar. Pada tahun 2016 berjumlah 1047 mahasiswa dimana untuk program studi ekonomi pembangunan berjumlah 84 mahasiswa, program studi manajemen berjumlah 575 mahasiswa, program studi akuntansi S1 berjumlah 362 mahasiswa dan program 
studi akuntansi D3 berjumlah 26 mahasiswa. Sedangkan tahun 2017 berjumlah 1065 mahasiswa dimana untuk program studi ekonomi pembangunan berjumlah 68 mahasiswa, program studi manajemen berjumlah 566 mahasiswa, program studi akuntansi S1 berjumlah 431 mahasiswa dan program studi akuntansi D3 berjumlah 23 mahasiswa. Dan pada tahun 2018 berjumlah 1040 mahasiswa dimana untuk program studi ekonomi pembangunan berjumlah 29 mahasiswa, program studi manajemen berjumlah 592 mahasiswa, program studi akuntansi S1 berjumlah 408 mahasiswa dan program studi akuntansi D3 berjumlah 11 mahasiswa. Jadi total keseluruhan mahasiswa aktif dari angkatan 2015-2018 berjumlah 4222 mahasiswa.

Namun yang menjadi subjek dalam penilitian ini adalah mahasiswa Fakultas Ekonomi Universitas Islam Riau Angkatan 2015-2017 dimana mahasiswa tersebut telah mempelajari mata kuliah ekonomi Islam di semester 3 untuk program studi ekonomi pembangunan, manajemen, akuntansi S1 dan program studi akuntansi D3 di semester 4. peneliti juga telah melakukan pra riset terhadap 50 mahasiswa Fakultas Ekonomi Universitas Islam Riau dengan mengajukan beberapa pertanyaan yang berhubungan dengan ekonomi syariah. Dari hasil pra riset dapat diambil kesimpulan bahwa mereka menjawab ekonomi syariah merupakan sistem ekonomi yang dalam penerapannya berlandaskan syariat Islam, mereka juga memilih untuk mengunakan sistem ekonomi syariah di bandingkan sistem ekonomi konvensional dalam menjalankan kegiatan ekonominya, dikarenakan sistem ekonomi syariah tidak terdapat riba, menggunakan sistem bagi hasil dan saling menguntungkan. Dari hasil pra riset yang telah dilakukan menunjukkan bahwa pendapat mereka terhadap ekonomi syariah di kategorikan "baik". Tetapi masih terdapat beberapa mahasiswa yang belum mengetahui bahwasanya ekonomi syariah dengan ekonomi Islam adalah sama.

\section{TINJAUAN PUSTAKA \\ Teori Persepsi}

Menurut Echols dan Shadily dalam Desmita (2011:30) menjelaskan bahwa persepsi merupakan sebuah istilah yang sudah sangat familiar didengar dalam percakapan sehari-hari. Istilah persepsi berasal dari bahasa Inggris "perception", yang diambil dari bahasa latin "perceptio", yang berarti menerima atau mengambil. Sedangkan secara istilah persepsi adalah cara seseorang menerima informasi atau menangkap sesuatu hal secara pribadi atau individu. Persepsi-persepsi ini membentuk apa yang dipikirkan, mendefenisikan apa yang penting dan selanjutnya juga akan menentukan bagaimana mengambil keputusan (Safuri, 2009:294).

Persepsi adalah perception yaitu cara pandang terhadap sesuatu atau mengutarakan pemahaman hasil olahan daya pikir, artinya persepsi berkaitan dengan faktor-faktor eksternal yang direspon melalui panca indra, daya ingat dan daya jiwa (Daulay, 2014:151).

Persepsi adalah pengalaman tentang objek, peristiwa atau hubungan-hubungan yang diperoleh dengan menyimpulkan informasi dan menafsirkan pesan. Persepsi ialah memberikan makna pada stimulus indrawi (sensory stimuli). Hubungan persepsi dan sensasi sudah jelas, sensasi adalah bagian dari persepsi (Rakhmat, 2015:50). Persepsi merupakan serangkaian proses rumit yang melaluinya kita memperoleh dan menginterprestasikan informasi indrawi. Interpertasi ini memungkinkan kita mencerap lingkungan 
kita secara bermakna (Ling \& Catling Jonathan, 2012:6).

Menurut Khairani (2013:63) persepsi adalah suatu proses pengindraan, stimulus yang diterima oleh individumelalui alat indra yang kemudian di interprestasikan sehingga indivudu dapat memahami dan mengerti tentang stimulus yang diterimanya tersebut. Pendapat lain Menurut Mc Shane dan Von Glinow dalam Thoha (2015:148), persepsi merupakan proses menerima informasi membuat pengertian tentang dunia di sekitar kita. Hal tersebut memerlukan pertimbangan informasi mana yang perlu diperhatiakn, bagaimana mengategorikan informasi dan bagaimana menginterprestasikan dalam kerangka kerja pengetahuan kita yang telah ada. Persepsi pada hakikatnya adalah proses kognitif yang dialami oleh setiap orang di dalam memahami informasi tentang lingkungannya, baik lewat penglihatan, pendengaran, penghayatan, perasaan dan penciuman. Kunci untuk memahami persepsi adalah terletak pada pengenalan bahwa persepsi itu merupakan suatu penafsiran yang unik terhadap situasi dan bukannya suatu pencatatan yang benar terhadap situasi.

\section{Faktor-faktor Mempengaruhi Persepsi}

Ada dua faktor yang mempengaruhi persepsi menurut Miftah Thoha (2015:149156)

a. Faktor-faktor dari luar (External perception)

Adapun faktor-faktor dari luar yang terdiri dari pengaruh-pengaruh lingkungan luar antara lain: intensitas, ukuran, keberlawanan, pengulangan, gerakan dan hal-hal baru. Berikut penjelasannya :

1) Intensitas. Prinsip intensitas dari suatu perhatian dapat dinyatakan bahwa semakin besar intensitas stimulus dari luar, layaknya semakin besar pula hal-hal itu dapat dipahami (to be perceived).

2) Ukuran. Faktor ini sangat dekat dengan prinsip intensitass di atas. Faktor ini menyatakan bahwa semakin besar ukuran suatu obyek maka semakian mudah untuk bisa diketahui atau dipahami.

3) Pengulangan. Dalam prinsip ini dikemukakan bahwa stimulus dari luar yang diulang akan memberikan perhatian yang lebih besar dibandingkan dengan yang sekali dilihat.

4) Gerakan. Prinsip gerakan ini antaranya menyatakan bahwa orang akan memberikan banyak perhatian terhadap obyek yang bergerak dalam jangkauan pandangannya dibandinngkan dari obyek yang diam. Persepsi ditimbulkan dari proses penarikan suatu obyek dan obyek yang bergerak akan lebih banyak menarik perhatian seseorang dibandingkan dengan obyek yang diam (stationary objects).

5) Kebaruan. Prinsip ini menyatakan bahwa baik situasi eksternal yang baru maupun yang sudah dikenal dapat digunakan sebagai penarik perhatian.

b. Faktor-faktor dari dalam (self perception)

Beberapa faktor dari dalam diri seseorang yang mempengaruhi proses seleksi persepsi antara lain, 


pemahaman, motivasi dan
kepribadiannya,
penjelasannya :
1) Pemahaman (learning).
Semua faktor-faktor dari
dalam yang membentuk
adanya perhatian kepada
sesuatu obyek sehingga
menimbulkan adanya
persepsi adalah didasarkan
dari kekomplekan kejiwaan.
Kekomplekan kejiwaan ini
selaras dengan proses
pemahaman atau belajar
(learning) dan motivasi yang
dimiliki oleh masing-masing
orang.

2) Motivasi. Faktor dari dalam lainnya yang juga menentukan terjadinya persepsi antara lain motivasi dan kepribadian. Walaupun motivasi dan kepribadian pada dasarnya tidak bisa dipisahkan dengan proses belajar, tetapi keduanya juga mempunyai dampak yang amat penting dalam proses pemilihan persepsi.

3) Kepribadian. Dalam membentuk persepsi unsur ini amat erat hubungannya dengan proses belajar dan motivasi yang dijelaskan di atas, yang mempunyai akibat tetang apa yang diperhatikan dalam menghadiri suatu situasi.

\section{Teori Ekonomi Syariah}

Kata ekonomi berasal dari kata Yunani, yaitu oikos dan nomos. Kata oikos berarti rumah tangga (house-hold), sedangkan kata nomos memiliki arti mengatur. Maka secara garis besar ekonomi diartikan sebagai aturan rumah tangga atau manajemen rumah tangga (Fauzia dan Abdul Kadir Riyadi 2014:2).

Menurut istilah pakar ekonomi, ekonomi adalah usaha untuk mendapatkan dan mengatur harta baik material maupun non-material untuk memenuhi kebutuhan hidup baik secara individu maupun kolektif , yang menyangkut perolehan, pendistribusian ataupun penggunaan untuk memenuhi kebutuhan hidup (Rusby 2014:26).

Sedangkan ekonomi Islam seperti dikemukakan SM. Hasanuzzaman adalah pengetahuan dan aplikasi ajaran-ajaran dan aturan-aturan syariah yang mencegah ketidakadilan dalam pencarian dan pengeluaran sumber-sumber daya guna memberikan kepuasan bagi manusia dan memungkinkan mereka melaksanakan kewajiban-kewajiban mereka terhadap Allah dan Masyarakat, kerena itulah keadilan ekonomi memiliki korelasi yang signifikan dengan keadilan dalam produksi (Effendi 2003:3).

Kata ekonomi syariah merupakan gabungan dari dua kata, yaitu "ekonomi" dan "syariah". Adapun, kata ekonomi berasal dari bahasa yunani, yaitu oikos nomos yang dalam bahasa inggris disebut dengan management of household or estate (tata laksana rumah tangga atau pemillikan) (Roysidi, 2014:4).

Ekonomi syariah merupakan ilmu pengetahuan sosial yang mempelajari masalah-masalah ekonomi rakyat yang dibatasi oleh nilai-nilai Islam. Adapun pengertian ekonomi syariah yang dikemukakan oleh Akram Khan adalah ekonomi Islam bertujuan untuk melakukan kajian tentang kebahagian hidup manusia yang dicapai dengan mengorganisasikan sumber daya alam atas dasar bekerja sama dan partisipasi (Manam 2012: 7).

Menurut Manan, ekonomi Islam adalah ilmu pengetahuan sosial yang mempelajari 
masalah-masalah ekonomi masyarakat yang di ilhami oleh nilai-nilai Islam (Manam 2012: 7).

Defenisi lain menurut Chapra, ekonomi Islam adalah sebuah pengetahuan yang membantu upaya realisasi kebahagian manusia melalui alokasi dan distribusi sumber daya yang terbatas yang berada dalam koridor yang mengacu pada pengajaran Islam tanpa memberikan kebebasan individu atau tanpa perilaku makro ekonomi yang berkesinambungan dan tanpa ketidak seimbangan lingkungan (Manam 2012: 7).

Muhammad Nejatullah Siddiqi memberikan defenisi ekonomi Islam yaitu ekonomi Islam adalah respons pemikir muslim terhadap tantangan ekonomi pada masa tertentu. Dalam usaha keras ini mereka dibantu oleh Alqur'an dan sunnah, akal (ijtihad) dan pengalaman (Manam 2012: 7).

Menurut Kursyid Ahmad, ekonomi Islam adalah sebuah usaha sistematis untuk memahami masalah-masalah ekonomi dan tingkah laku manusia secara relasional dalam persfektif Islam (Manam 2012: 8).

Sementara Sayed Nawab Haider Naqui menyatakan ekonomi Islam adalah ekonomi Islam merupakan representasi perilaku muslim dalam suatu masyarakat muslim tertentu (Manam 2012: 8).

Sedangkan menurut Munawar Iqbal ekonomi Islam adalah sebuah disiplin ilmu yang mempunyai akar dalam syariat Islam. Islam memandang wahyu sebagai sumber ilmu pengetahuan yang paling utama. Prinsip-prinsip dasar yang dicantumkan dalam Al-qur'an dan Al-hadis adalah batu ujian untuk menilai teori-teori baru berdasarkan doktrin-doktrin ekonomi Islam (Manam 2012: 8).

Dari keterangan di atas, dapat disimpulkan bahwa ilmu ekonomi syariah adalah ilmu yang mengatur penghidupan manusia secara aktual, baik dalam produksi, distribusi, maupun komsumsi sesuai dengan syariat Islam berdasarkan Alqur'an, hadis serta ijma' para ulama, untuk mencapai kebahagiaan dunia dan akhirat. Adapun persamaan dari pengertian ekonomi Islam dengan ekonomi syariah adalah berpedoman kepada Al-qur'an dan Hadis, sama-sama mempelajari ilmu pengetahuan tentang ekonomi yang dibatasi dengan nilai-nilai Islam, dalam pelaksanaanya bertujuan untuk mendapatkan kebahagiaan di dunia maupun di akhirat.

\section{Prinsip-prinsip Ekonomi Syariah}

Terdapat berbagai prinsip yang harus di pegang teguh dalam menjalankan ekonomi syariah, adapun prinsip-prinsip dalam ekonomi syariah adalah sebagai berikut (Mujahidin, 2007:12).

a. Tauhid. Tauhid merupakan pondasi ajaran Islam. Dengan tauhid, manusia menyaksikan bahwa "tiada sesuatupun yang layak disembah selain Allah" dan "tidak ada pemilik langit, bumi dan seisinya selain dari pada Allah" karena Allah adalah pencipta alam semesta dan isinya dan sekaligus pemiliknya, termasuk pemilik manusia dan seluruh sumber daya yang ada.

b. 'Adl. Allah adalah pencipta segala sesuatu dan salah satu sifat-Nya adalah adil, tidak membeda-bedakan perlakuan terhadap makhluk-Nya secara dzalim.

c. Nubuwah. Karena sifat rahmad, Rahim dan bijaksanaan Allah, manusia tidak dibiarkan begitu saja di dunia tanpa mendapat bimbingan.

1) Shidiq (jujur, benar)

2) Amanah (tanggung jawab, dapat dipercaya, kredibilitas)

3) Fathonah (kecerdikan, kebijaksanaan, intelektualitas) 
4) Tabligh (komunikasi, keterbukaan, pemasaran)

d. Khilafah. Dalam Al-Quran Allah berfirman bahwa manusia diciptakan untuk menjadi khalifah di bumi, artinya untuk menjadi pemimpin dan pemakmur bumi. Karena itu pada dasarnya manusia adalah pemimpin.

e. Ma'ad. Walaupun seringkali diterjemahkan sebagai "kebangkitan", tetapi secara harfiah ma'ad berarti "kembali". Dan kita akan selalu kembali kepada Allah. Hidup manusia bukan hanya di dunia, tetapi terus berlanjut hingga alam akhirat.

\section{Ciri-ciri Ekonomi Syariah}

Menurut pendapat Suprayetno (2005: 4-6) adapun ciri-ciri dari ekonomi syariah adalah sebagai berikut:

a. Pemilikan. Oleh karena manusia itu berfungsi sebagai khalifah yang berkewajiban untuk mengelola alam ini guna kepentingan umat manusia maka ia berkewajiban mempertanggung jawabkan pengelola sumber daya alam.

b. Atau dijadikan modal untuk suatu perusahaan swasta, atau ikut ambil bagian dari modal uang di tawarkan untuk investasi.

c. Pelaksanaan perintah untuk berlomba - lomba berbuat baik.

d. Thaharah atau sesuci, kebersihan.

e. Produk barang dan jasa harus halal.

f. Keseimbangan.

g. Upah tenaga kerja, keuntungan dan margin.

h. Upah harus dibayar dan jangan menunggu hingga keringatnya kering

i. Bekerja baik dan beribadah.

j. Kejujuran dan tepati janji.

k. Kelancaran pembangunan.

Tujuan Ekonomi Syariah

Tujuan akhir ekonomi syariah adalah sebagaimana tujuan dari syariat Islam itu sendiri (muqashid asy syari'ah), yaitu mencapai kebahagian di dunia dan di akhirat (falah) melalui suatu tata kehidupan yang baik dan terhormat (hayyah thayyibah). Inilah kebahagian hakiki yang diinginkan oleh setiap manusia, bukan kebahagiaan semua yang sering kali pada akhirnya justru melahirkan penderitaan dan kesengsaraan.

Mewujudkan kesejahteraan hakiki bagi manusai merupakan dasar sekaligus tujuan utama dari syariat Islam (maslahah al ibad), karenanya juga merupakan tujuan ekonomi syariah. Menurut As-Shatibi, tujuan utama syariat Islam adalah mencapai kesejahteraan manusia yang terletak pada perlindungan terhadap lima ke-mashlahahan, yaitu keimanan (ad-dien), ilmu (al-'lim), kehidupan (an-nafs), harta (al-maal), dan kelangsungan keturunan (an-nasl). Kelima mashlahah tersebut pada dasarnya merupakan sarana yang sangat dibutuhkan bagi kelangsungan kehidupan yang baik dan terhormat. Jika salah satu dari ilmu kebutuhan ini tidak tercukupi, niscaya manusia tidak akan mencapai kesejahteraan yang sesungguhnya.

Sedang menurut pendapat umar chaptra menjelaskan bahwa tujuan-tujuan tatanan ekonomi syariah adalah sebagai berikut (Rais, 2005: 35).

a. Kesejahteraan ekonomi di dalam kerangka norma-norma moral Islam.

b. Persaudaraan universal dan keadilan.

c. Pemerataan pemasukan.

d. Kebebesan individu di dalam konteks kesejahteraan sosial.

Jadi tujuan ekonomi syariah sebagaimana yang dijelaskan oleh umar chapra tersebut bersifat universal.

\section{Keistimewaan dan Karakteristik Ekonomi Syariah}

Keistimewaan dan karakteristik ekonomi syariah terdapat 5 keistimewaan yaitu: 
a. Ekonomi syariah merupakan bagian yang tidak terpisahkan dari konsep syariah yang utuh dan menyeluruh.

b. Ekonomi syariah merupakan suatu bentuk ibadah.

c. Tatanan ekonomi syariah memiliki tujuan yang sangat mulia.

d. Ekonomi syariah merupakan sistem yang memiliki pengawasan melekat yang berakar dari keimanan dan tanggung jawab kepada Allah SWT (muraqabatullah).

e. Ekonomi syariah merupakan sistem yang menyelaraskan antara maslahat individu dan maslahat umum.

\section{Landasan Hukum Ekonomi Syariah}

Adapun landasan ekonomi syariah adalah sebagai berikut :

$\mathrm{a}_{\overline{\mathrm{N}}} \quad$ Al-quran (QS Al-Baqarah: 275)

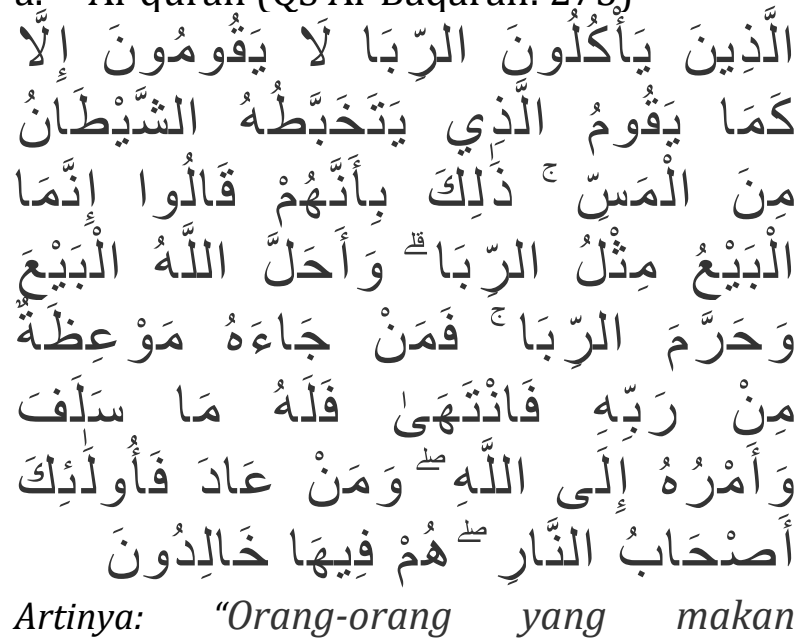

(mengambil) riba tidak dapat berdiri melainkan seperti berdirinya orang yang kemasukan syaitan lantaran (tekanan) penyakit gila. Keadaan mereka yang demikian itu, adalah disebabkan mereka berkata (berpendapat), sesungguhnya jual beli itu sama dengan riba, padahal Allah telah menghalalkan jual beli dan mengharamkan riba. Orang-orang yang telah sampai kepadanya larangan dari Tuhannya, lalu terus berhenti (dari mengambil riba), maka baginya apa yang telah diambilnya dahulu (sebelum datang larangan); dan urusannya (terserah) kepada Allah. Orang yang kembali (mengambil riba), maka orang itu adalah penghunipenghuni neraka; mereka kekal di dalamnya"(QS- Al- Baqarah: 275)

\section{b. Hadist}

Perilaku jujur, misalnya, dalam masyarakat dipandang sebagai sikap etis, baik dalam percaturan ekonomi ataupun kehidupan sosial umumnya. Dalam hal kejujuran dalam ekonomi, Nabi Muhammad SAW bersabda :

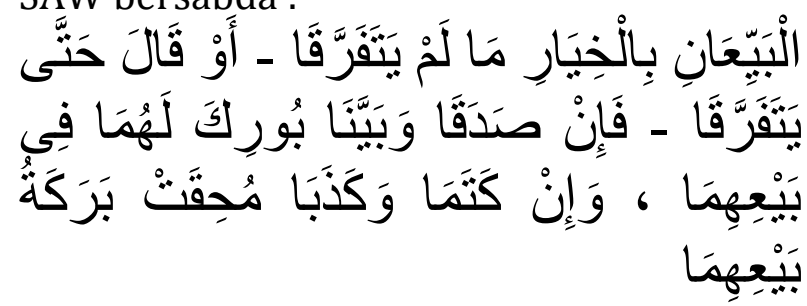

artinya: "Kedua orang penjual dan pembeli masing-masing memiliki hak pilih (khiyar) selama keduanya belum berpisah. Bila keduanya berlaku jujur dan saling terus terang, maka keduanya akan memperoleh keberkahan dalam transaksi tersebut. Sebaliknya, bila mereka berlaku dusta dan saling menutup-nutupi, niscaya akan hilanglah keberkahan bagi mereka pada transaksi itu". (HR. Bukhari dan Muslim).

\section{METODE}

Jenis penelitian ini adalah Penelitian ini termasuk dalam jenis penelitian Lapangan (Field Reasearch) dengan mengunakan penelitian Deskriptif (Leksono 2013: 181). Yaitu desain penelitian yang disusun dalam rangka memberikan gambaran secara sistematis tentang informasi ilmiah yang berasal dari subjek atau objek penelitian (Sanusi, 2011: 13).

Penelitian ini dilakukan di Fakultas Ekonomi Universitas Islam Riau pada bulan April sampai dengan Juli 2019. Dalam penelitian ini yang dijadikan populasi adalah mahasiswa semester 4-8 Fakultas 
Ekonomi Universitas Islam Riau. Berdasarkan data yang diperoleh dari Tata Usaha Maka diperoleh total populasinya berjumlah 3182 Mahasiswa.

Mengingat pentingnya persepsi terhadap ekonomi syariah, maka penulis melakukan pengambilan sampel dengan menggunakan rumus slovin, karena banyaknya populasi yang akan dijadikan sebagai subjek dalam penelitian ini.

Rumus $n=\frac{N}{1+N(e)^{2}}$

keterangan :

$\mathrm{n}=$ jumlah sampel

$\mathrm{N}=$ ukuran populasi

$\mathrm{e}=$ toleransi ketidak telitiaan $(7 \%)$

Dalam penelitian ini jumlah populasi adalah 3182 mahasiswa dengan toleransi ketidak telitian sebesar $7 \%$ maka ukuran sampel sebagai berikut :

$$
\begin{aligned}
& n=\frac{3182}{1+3182(7 \%)^{2}} \\
& n=187
\end{aligned}
$$

Dapat diketahui bahwa sampel dalam penelitian ini adalah 187 mahasiswa dan teknik pengambilan sampel dalam penelitian ini adalah menggunakan random sampling, yaitu pengambilan sampel secara acak dimana anggota sampelnya mendapatkan kesempatan yang sama untuk dijadikan sampel.

Untuk melengkapi data yang diperlukan dalam penelitian ini metode yang digunakan adalah :

1) Angket atau kuesioner yaitu daftar pernyataan atau pertanyaan yang diberikan kepada mahasiswa yang bersedia memberikan respons sesuai dengan permintaan penulis, Pengukuran variabel dilakukan dengan mengunakan skala lima alternatif pilihan (skala likert). Setiap variabel diberikan skor sebagai berikut :
(SS) Sangat Setuju
$=$ skor 5
(S) Setuju
$=$ skor 4
(N) Netral
$=$ skor 3
(TS) Tidak Setuju
$=$ skor 2
(STS) Sangat Tidak Setuju
$=$ skor 1

2) Dokumentasi yaitu bahan-bahan dokumentasi yang berhubungan dengan masalah dalam peneletian ini.

\section{HASIL \\ Sejarah Singkat Fakultas Ekonomi Universitas Islam Riau}

Fakultas Ekonomi UIR secara resmi dibuka oleh Yayasan Pendidikan Islam (YLPI) Daerah Riau pada tanggal 1 Juli 1981 bedasarkan SK. No. 19/Kep. 1 ?1978 dengan kegiatan operasional dimulai pada tanggal 22 Agustus 1981. Sebelum Fakultas Ekonomi berdiri sudah ada Akademi Akuntansi dan Akademi Sekretaris Manajemen yang pada dasarnya merupakan cikal bakal berdirinya Fakultas Ekonomi. Pada perkembangan selanjutnya Akademi Akuntansi merupakan salah satu Program Studi yang bernaung dibawah Fakultas Ekonomi dengan nama program Akuntansi D.III, sedangkan ASMI selanjutnya diasuh oleh Fakultas Ilmu Sosial dan Politik yang berganti nama menjadi Program D.III Kesekretariatan.

Dari tahun 1981 sampai dengan awal tahun 1985 Fakultas Ekonomi berlokasi di Kampus lama jalan Prof. Yamin No. 1 Pekanbaru. Sejak awal tahun 1985, seiring dengan semakin meningkatnya aktivitas dan kapasitas masing-masing jurusan maka Fakultas Ekonomi pindah ke Kampus Baru di Perhentian Marpoyan Pekanbaru yang sekarang bernama JI. Kaharuddin Nasution KM 11 Marpoyan Pekanbaru. Fakultas Ekonomi memperoleh izin operasional dari pernerintah c.q Kopertis Wilayah I Medan 
berdasarkan SK. No. 025/PD/Kop.1/1981 tertanggal 24 Agustus 1981. kemudian pada tanggal 2 November 1984 status Fakultas Ekonomi ditingkatkan menjadi Terdaftar berdasarkan SK. No. 03240/DIKBUD/1984. Pada tahun 1987 program Akuntansi D.III ditingkatkan statusnya dari Terdaftar menjadi Diakui dan pada tahun 1990 dinaikkan menjadi Status Disamakan berdasarkan SK Dirjen Dikti N 044/0/90 tanggal 17 Januari 1990.

Berdasarkan evaluasi dari Kopertis Wilayah I maka mulai: juni 1990 Status progaram Studi Manajemen dan Studi Pernbangunan ditingkatkan statusnya dari terdaftar menjadi Diakui berdasarkan SK Mendikbud RI No. 0379/0/1990 dan No. 0380/0/194. tertanggal 31 Mei 1990 yang kemudian meningkat menjadi status disamakan berdasarkan SK. Dirjen Dikti No. 441/Dikti/Kep/92 tanggal 16 Oktober 1992. Jurusan Akuntansi/S1 mulai dibuka pada tahun 1986.

\section{PEMBAHASAN}

Tabel 2 : Rekapitulasi Data Angket Persepsi Mahasiswa Fakultas Ekonomi Universitas Islam Riau Tentang Ekonomi Syariah

\begin{tabular}{|l|l|c|c|c|c|c|c|}
\hline \multirow{2}{*}{ No } & \multirow{2}{*}{ Pernyataan } & \multicolumn{4}{|c|}{ Rekapitulasi Perhitungan Data Angket } & \multirow{2}{*}{ Sangat } \\
\cline { 3 - 7 } & & Setuju & Setuju & Netral & $\begin{array}{l}\text { Tidak } \\
\text { Setuju }\end{array}$ & $\begin{array}{l}\text { Sangat } \\
\text { Tidak } \\
\text { Setuju }\end{array}$ & \\
\hline 1 & Pernyataan 1 & 45 & 73 & 66 & 3 & 0 & 187 \\
\hline 2 & Pernyataan 2 & 35 & 74 & 69 & 9 & 0 & 187 \\
\hline 3 & Pernyataan 3 & 60 & 96 & 30 & 1 & 0 & 187 \\
\hline 4 & Pernyataan 4 & 50 & 99 & 38 & 0 & 0 & 187 \\
\hline 5 & Pernyataan 5 & 22 & 83 & 60 & 18 & 4 & 187 \\
\hline 6 & Pernyataan 6 & 26 & 99 & 56 & 4 & 2 & 187 \\
\hline 7 & Pernyataan 7 & 28 & 76 & 78 & 3 & 2 & 187 \\
\hline
\end{tabular}




\begin{tabular}{|l|l|c|c|c|c|c|r|}
\hline 8 & Pernyataan 8 & 36 & 70 & 51 & 28 & 2 & 187 \\
\hline 9 & Pernyataan 9 & 55 & 91 & 37 & 4 & 0 & 187 \\
\hline 10 & Pernyataan 10 & 41 & 102 & 43 & 1 & 0 & 187 \\
\hline 11 & Pernyataan 11 & 29 & 94 & 61 & 3 & 0 & 187 \\
\hline 12 & Pernyataan 12 & 16 & 97 & 72 & 2 & 0 & 187 \\
\hline 13 & Pernyataan 13 & 32 & 117 & 35 & 3 & 0 & 187 \\
\hline 14 & Pernyataan 14 & 34 & 106 & 43 & 2 & 2 & 187 \\
\hline 15 & Pernyataan 15 & 54 & 100 & 31 & 2 & 0 & 187 \\
\hline 16 & Pernyataan 16 & 22 & 102 & 61 & 0 & 2 & 187 \\
\hline 17 & Pernyataan 17 & 17 & 93 & 77 & 0 & 0 & 187 \\
\hline 18 & Pernyataan 18 & 25 & 97 & 65 & 0 & 0 & 187 \\
\hline 19 & Pernyataan 19 & 33 & 77 & 64 & 11 & 2 & 187 \\
\hline 20 & Pernyataan 20 & 31 & 84 & 69 & 3 & 0 & 187 \\
\hline Jumlah & 691 & 1830 & 1106 & 97 & 16 & 3740 \\
\hline \multicolumn{2}{|l|}{ Nilai Total } & 5 & 4 & 3 & 2 & 1 & \\
\hline \multicolumn{2}{|l|}{ Total Skor } & 3455 & 7320 & 3318 & 194 & 16 & \\
\hline \multicolumn{2}{|l|}{ Grand Total Skor } & & & & & & 14303 \\
\hline \multicolumn{2}{|l|}{ Rata-Rata Skor } & & & & & & 715 \\
\hline \multicolumn{2}{|l|}{ Persentase } & $24 \%$ & $51 \%$ & $23 \%$ & $2 \%$ & $0 \%$ & $100 \%$ \\
\hline
\end{tabular}

\section{Sumber: Data Olahan 2019}

Berdasarkan tabel di atas dapat dilihat bahwa tanggapan responden mengenai persepsi mahasiswa Fakultas Ekonomi Universitas Islam Riau Tentang Ekonomi Syariah menyatakan setuju yaitu dengan persentase $51 \%$
Berdasarkan tabel di atas dapat digambarkan melalui diagram lingkar sebagai berikut: 


\section{Gambar 1 : Diagram Lingkar Persepsi Mahasiswa Fakultas Ekonomi Universitas Islam Riau Tentang Ekonomi Syariah}

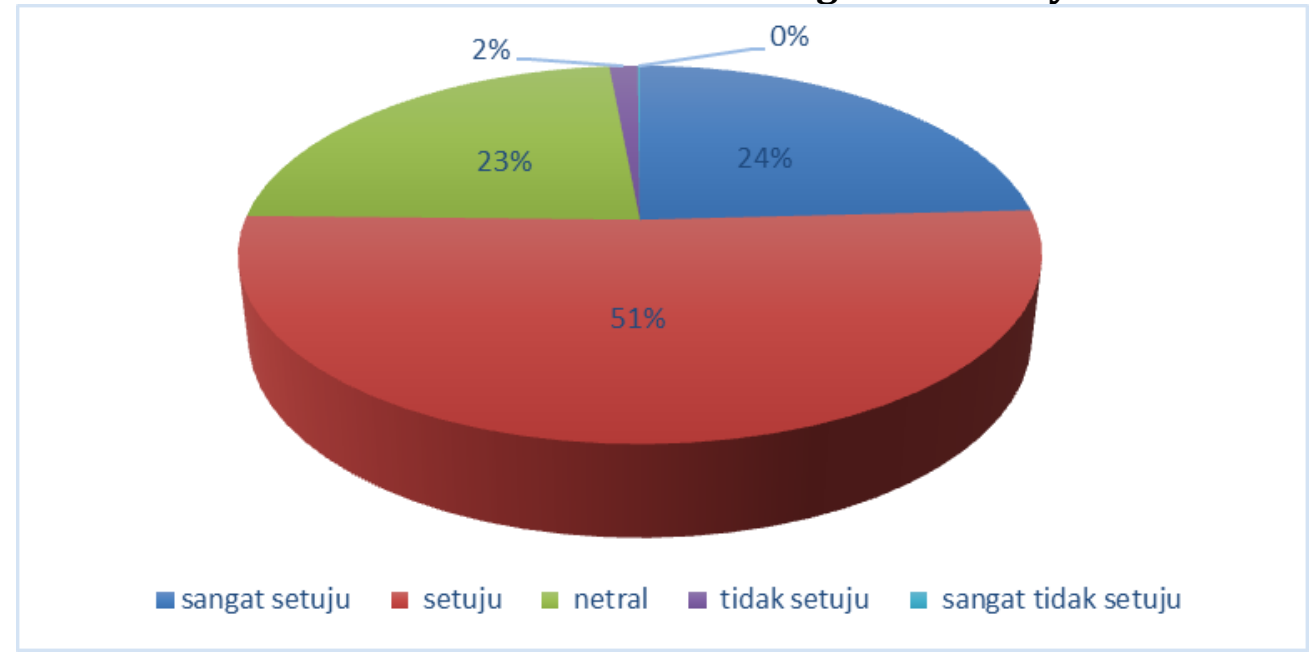

Sumber: Data Olahan 2019

Berdasarkan gambar di atas dapat disimpulkan bahwa sebagian responden memiliki dimensi faktor-faktor yang mempengaruhi persepsi mahasiswa Fakultas Ekonomi UIR tentang ekonomi syariah. Terlihat dari tanggapan responden yang menyatakan setuju dengan persentase $51 \%$.
Berdasarkan data skor yang telah ditetapkan di atas, maka selanjutnya dihitung jawaban dari responden yang akan dibandingkan dengan skor ideal (kriterium) (Sugiono 2013:95), disajikan sebagai berikut :

\section{Gambar 2 : Perbandingan Skor Ideal}

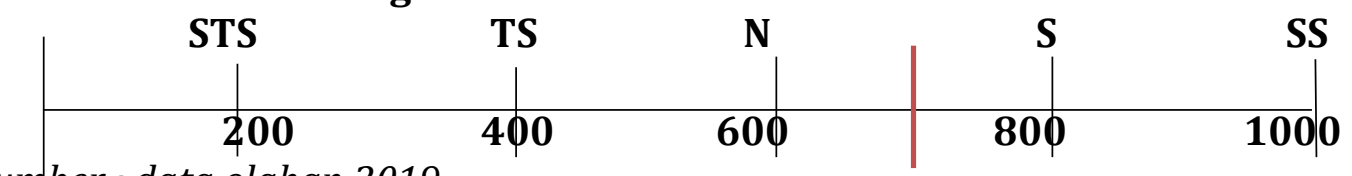

Sumber : data olahan 2019

Dari hasil perhitungan pada skor ideal (kriterium) diketahui bahwa persepsi mahasiswa Fakultas Ekonomi Universitas Islam Riau tentang ekonomi syariah adalah "setuju", karena akumulasi jawaban responden berada pada kontinum skor ideal (kriterium) 715 pada daerah setuju.

Berdasarkan dimensi faktor eksternal pada pernyataan nomor 1 - 13 tanggapan responden yang menyatakan sangat setuju sebanyak 475 orang atau $20 \%$, responden yang menyatakan setuju sebanyak 1177 orang atau $48 \%$, responden yang menyataakan netral sebanyak 696 orang atau $29 \%$, responden yang menyatakan tidak setuju sebanyak 79 orang atau $2 \%$ dan responden yang menyatakan sangat tidak setuju setuju sebanyak 10 orang atau $1 \%$. Dari keterangan di atas dapat disimpulkan bahwa sebagian mahasiswa Fakultas Ekonomi UIR memiliki faktor internal terlihat dari tanggapan responden yang menyatakan setuju sebesar $48 \%$.

Berdasarkan dimensi faktor internal pada pernyataan nomor 14 - 20 tanggapan responden yang menyatakan sangat setuju sebanyak 216 orang dengan persetase 17 $\%$, responden yang menyatakan setuju 
sebanyak 659 orang atau $50 \%$, responden yang menyataakan netral sebanyak 410 orang atau $31 \%$, responden yang menyatakan tidak setuju sebanyak 18 orang atau $1 \%$, dan responden yang menyatakan sangat tidak setuju setuju sebanyak 6 orang atau $1 \%$ Dari keterangan di atas dapat disimpulkan bahwa sebagian mahasiswa Fakultas Ekonomi UIR memiliki faktor internal terlihat dari tanggapan responden yang menyatakan setuju sebesar $50 \%$.

Berdasarkan dimensi faktor-faktor persepsi tanggapan responden yang menyatakan sangat setuju sebanyak 3455 atau $24 \%$, responden yang menyatakan setuju sebanyak 7320 atau $51 \%$, responden yang menyatakan netral sebanyak 3318 atau 23\%, responden yang menyatakan tidak setuju sebanyak 194 atau $2 \%$ dan responden yang menyatakan sangat tidak setuju sebanyak 16 orang atau $0 \%$.

Jika dilihat dari interprestasiskor penelitian yaitu $(14303 / 18700 \times 100=$ $72 \%$ maka penelitian ini menunjukkan bahwa persepsi mahasiswa Fakultas Ekonomi Universitas Islam Riau tentang ekonomi syariah berada dalam kategori "Baik".

\section{SIMPULAN}

Berdasarkan hasil dari pembahasan persepsi mahasiswa Fakultas Ekonomi Universitas Islam Riau tentang ekonomi syariah yang telah di olah melalui jawaban responden yang populasinya sebanyak 3182 orang dengan sampel sebanyak 187 orang mahasiswa. Respon mahasiswa terhadap ekonomi syariah termasuk baik dimana minat mahasiswa yang mengikuti organisasi ForSEI terus meningkat dan para dosen dan tata usaha Fakultas Ekonomi sering kali membicarakan tentang ekonomi syariah.
Berdasarkan dimensi "faktor-faktor Eksternal" dari deskripsi di atas dapat disimpulkan bahwa responden telah memiliki gambaran faktor-faktor Eksternal yang mempengaruhi persepsi mahasiswa Fakultas Ekonomi Tentang Ekonomi Syariah dengan tingginya jawaban responden menyatakan setuju.

Berdasarkan dimensi "faktor-faktor Internal" dari deskripsi di atas dapa disimpulkan bahwa responden telah memiliki gambaran faktor-faktor Internal yang mempengaruhi persepsi mahasiswa Fakultas Ekonomi Tentang Ekonomi Syariah dengan tingginya jawaban responden menyatakan setuju.

Berdasarkan hasil interprestasi dengan skor dan pengukuran maka dapat disimpulkan bahwa persepsi berada pada skor 715 adalah "Setuju", dengan persentase $72 \%$ yang berarti persepsi mahasiswa Fakultas Ekonomi Universitas Islam Riau tentang ekonomi syariah adalah "Baik".

\section{DAFTAR RUJUKAN}

Daulay, Nurussakinah. (2014). Pengantar Psikologi Dan Pandangan Al-Qur'an Tentang Psikologi. Prenda Media Group, Jakarta.

Desmita. (2011). Psikologi Perkembangan Peserta Didik. PT Remaja Rosdakarya, Bandung.

Effendi, Rustam. (2003). Produksi Dalam Islam. Magistra Insania Press, Yogyakarta.

Fauzia, Ika Yunia Dan Abdul Kadir Riyadi. (2014). Prinsip Dasar Ekonomi Islam: Prespektif Maqashid Al-Syari'ah. Kencana, Jakarta.

Khairani, Makmun. (2013). Psikologi Umum. Aswaja Pressindo, Yogyakarta.

Ling, Jonathan Dan Jhonathan Calting. (2012). Psikologi Kognitif. PT Gelora Aksara Pratama, Jakarta. 
Manam, Abdul. (2012). Hukum Ekonomi Syariah: Dalam Perspektif Kewenangan Peradilan Agama, Kencana, Jakarta.

Mujahidin, Ahmad. (2007). Ekonomi Islam, Ed 1. Raja Grafindo Persada, Jakarta.

Rais, Salsi. (2005). Pegadaian Syariah Konsep Dan Sistem Operasional Suatu Kajian Konteporer. Universitas Indonesia (Ui-Press), Jakarta.

Rahmat, Jalaluddin. (2015). Psikologi Komunikasi. PT Remaja Rosdakarya, Bandung.

Rusby, Zulkifli. (2014). Pemikiran Ekonomi Dalam Islam. Pusat Kajian Pendidikan Islam FAI UIR, Pekanbaru.

Safuri, Rafy. (2009). Psikologi Islam. PT Raja Grafindo Persada, Jakarta.

Sanusi, Anwar. (2011). Metode Penelitian Bisnis. Selemba Empat, Jakarta.

Sugiono. (2013). Metode Penelitian Kualitatif, Kuantitatif dan $R \& D$. Alfabeta, Bandung.

Thoha, Miftah. (2015). Perilaku Organisasi Konsep Dasar Dan Aplikasinya. PT Raja Grafindo Persada, Jakarta. 